\title{
REVIEW OF CONTEXT AND COMMUNICATION CONTENT IN SECONDARY TRADITIONAL COMMUNITIES SECONDARY VILLAGE
}

\section{TINJAUAN KONTEKS DAN KONTEN KOMUNIKASI PADA KOMUNITAS ADAT TERPENCIL DESA SEKAMIS Ardiyansyah \\ Program Studi IImu Komunikasi \\ Sekolah Tinggi IImu Sosial dan IImu Politik (STISIP NH) Jambi \\ Email: ardivansyah,ik@gmail.com}

\begin{abstract}
How to Cite :
Ardiyansyah (2020). Tinjauan Konteks Dan Konten Komunikasi Pada Komunitas Adat Terpencil Desa Sekamis. SENGKUNI Journal- Social Sciences and Humanities. DOI: https://doi.org/10.37638/sengkuni.1.1.37-45
\end{abstract}

\section{ARTICLE HISTORY}

Received [8 Maret 2020]

Revised [6 April 2020]

Accepted [20 April 2020]

\section{KEYWORDS}

Context, Content, Communication, KAT

This is an open access article under the $\underline{C C-B Y-S A}$ license

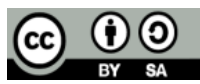

\section{ABSTRAK}

Fenomena tuntutan zaman yang semakin modern dan semakin maju membuat Komunitas Adat Terpencil yang dikenal dengan sebutan Suku Anak Dalam mau tidak mau harus terlibat dalam berbagai konteks komunikasi. Penelitian ini bertujuan Untuk mengetahui bentuk atau konteks komunikasi yang belangsung pada Komunitas Adat Terpencil, serta melihat konten atau unsur pesan dalam membangun komunikasi saat interaksai sosial Suku Anak Dalam di tengah kehidupan masyarakat luar yang mayoritas melayu di Desa Sekamis Sarolangun Jambi.

Penelitian ini dianalisis menggunakan konsep konteks konteks komunkasi dengan Metode Kualitatif. mendeskripsikan dan menganalisa fenomena dan aktivitas sosial Suku Anak Dalam. Data digali melalui wawancara mendalam dikomunitas Suku Anak Dalam, observasi lapangan terstruktur dan dokumentasi. Teknik analisis data yang digunakan yaitu yang dikemukakan menurut Matthew B. Miles dan A. Michael Huberman (dalam Sugiyono, 2012:246) terdapat tiga komponen yaitu: Reduksi Data, Penyajian Data dan Verifikasi/ Penarikan Kesimpulan.

Temuan di lapangan dan hasil analisis menunjukkan bahwa konteks dan konten Komunikasi pada Komunitas Adat Terpencil yaitu menggunakan Komunikasi Interpersonal, Komunikasi Kelompok, Komunikasi Organisasi.

\section{ABSTRACT}

The phenomenon of the demands of an increasingly modern and increasingly advanced era makes Remote Indigenous Communities known as the Suku Anak Dalam inevitably have to be involved in various communication contexts. This study aims to determine the form or context of communication that takes place in Remote Indigenous Communities, and see the content or elements of messages in building communication during the social interaction of Suku Anak Dalam in the midst of the life of the majority of Malay 
people in Saramangun, Sekamis Village, Jambi. This study was analyzed using the concept of the context of communication contexts with the Qualitative Method. describe and analyze the phenomena and social activities of the Anak Dalam Tribe. Data was collected through in-depth interviews in the Anak Dalam community, structured field observations and documentation. The data analysis technique used is that according to Matthew B. Miles and A. Michael Huberman (in Sugiyono, 2012: 246) there are three components, namely: Data Reduction, Data Presentation and Verification / Withdrawal of Conclusions. Field findings and analysis results show that the context and content of Communication in Remote Indigenous Communities is using Interpersonal Communication, Group Communication, Organizational Communication.

\section{PENDAHULUAN}

Setiap Suku Anak Dalam merupakan sebutan diri bagi komunitas adat terpencil yang hidup dan tersebar dalam hutan di provinsi Jambi dan provinsi Sumatera Selatan. Sebutan ini menurut mereka sebagai interpretasi dari kehidupan mereka yang sejak nenek moyangnya menggantungkan hidup pada hutan dan hasil-hasilnya. Pemerintah menamai komunitas ini dengan sebutan yang berubah-ubah sesuai dengan proyek yang akan diberlakukan untuk komunitas ini. Diawali dengan sebutan suku terasing, yang merupakan generalisasi untuk semua suku yang dianggap "belum hidup normal".

Suku Anak Dalam (SAD) merupakan salah satu etnik tradisional yang ada di Indonesia. Mereka bermukim di kawasan Desa Sekamis Kecamatan Batang Asai Kabupaten Sarolangun. Secara administratif kawasan Desa Sekamis terletak di antara Kecematan Batang Asai dan Kecematan Cerminan Gedang tepat berada pada lintasan jalan Batang Asai menuju ke Kota Sarolangun yang termasuk dalam Provinsi Jambi.

Kemudian mereka dinamai Komunitas Adat Terpencil, yang berikutnya disebut Suku Anak Dalam (SAD). Sedangkan istilah Kubu merupakan sebutan yang dilekatkan oleh masyarakat Melayu pada komunitas ini. Kubu diartikan hidup liar, kotor, bau, penuh dengan kekuatan mistis, bodoh dan tertutup. Makanya penyebutan kubu ini sangat ditentang oleh Orang Rimba, dan kemudian mereka menyebutkan identitas mereka sebagai Suku Anak Dalam (Aritonang, Robert et.al. 2010).

Suku Anak Dalam merupakan salah satu masyarakat adat yang berada di pedalaman hutan Sumatra. Bagi pemerintah (Kementrian Sosial) ciri-ciri golongan masyarakat yang digambarkan seperti Suku Anak Dalam adalah termasuk dalam golongan masyarakat terasing atau disebut sebagai KAT (Kelompok Adat Terpencil). Masyarakat terasing berdasarkan SK Menteri Sosial RI No. 5/1994 adalah kelompokkelompok masyarakat yang bertempat tinggal atau berkelana ditempat-tempat yang secara geografik terpencil, terisolir, dan secara sosial budaya terasing dan atau masih terkebelakang dibandingkan dengan masyarakat bangsa Indonesia padaumumnya.

Kelompok masyarakat terasing dengan ciri-ciri demikian diatas seperti Suku Anak Dalam ini oleh Depsos dianggap sebagai suatu masyarakat yang rentan terhadap berbagai permasalahan sosial atau disebut sebagai rawan sosial dimana keadaan mereka dipandang labil atau tidak mempunyai ketidakmantapan sosial politik yang akan menimbulkan permasalahan sosial karena kebudayaan mereka yang dianggap 
tidak lagi sesuai dengan masanya karena terisolir, baik secara geografis maupun budaya.

Menurut UUD 1945 Pasal 18B(2): Negara mengakui dan menghormati kesatuankesatuan masyarakat hukum adat beserta hak-hak tradisionalnya sepanjang masih hidup dan sesuai dengan perkembangan masyarakat dan prinsip Negara Kesatuan Republik Indonesia, yang diatur dalam undang-undang, dan Pasal 28I (3) Identitas budaya dan hak masyarakat tradisional dihormati selaras dengan perkembangan zaman dan peradaban. Masyarakat adat Suku Anak Dalam seringkali tidak terwakili aspirasinya dalam proses pembangunan atau tidak mendapatkan keuntungan dari proses tersebut. Sebagai warga negara, masyarakat adat harus menikmati hak dan kewajiban yang adil dan sejajar dengan masyarakat lainnya, masyarakat adat harus diberikan keleluasaan untuk melindungi dirinya dan budayanya serta menolak perubahan yang berdampak negatif bagi penghidupannya.

Pada dasarnya Suku Anak Dalam hidup secara berkelompok yang tidak dibatasi oleh wilayah tempat tinggal tertentu. Adat mereka mengautur untuk bebas tinggal bersama kelompok lain, namun demikian tidak mudah untuk berganti-ganti kelompok atau ataupun pemimpin karena adanya ikatan hukum adat yang kokoh. Seorang kepala suku merupakan hasil dari kompetisi yang ketat dikalangan laki-laki mereka harus mendapat persetujuan dari masyarakat atau anggota kelompok. Sistem sosial dan budaya mereka lebih kompleks dan terpadu dengan sistem hirarki kepemimpinan politik dengan banyak tingkat dan gelar. Hirarki ini bukan semata-mata manyangkut hak komando yang jelas dan diduduki berdasarkan prinsip suksesi yang jelas, posisi kepemimpinan serta posisi itu merupakan hasil dari kompetensi yang hebat antara lelaki yang berambisi. Mereka harus mendapat dukungan dan persetujuan dari masyarakatnya lewat berbagai cara.

Hal menarik lainnya untuk diketahui adalah tentang konteks-konteks komunikasi yang dilakukan Suku Anak Dalam berikut dengan kontennya dari unsur pesan komunikasi yang dilakukan. Seperti yang kita ketahui, komunikasi merupakan aspek yang sangat penting dalam menjalin atau melakukan interaksi sesama manusia, coba kita bayangkan jika semua orang dimuka bumi ini tidak ada yang pandai berkomunikasi atau yang paling kecil jika tidak adanya bahasa Indonesia entah bagaimana jadinya kehidupan di Indonesia. Komunikasi yang kita lakukan antara sesama orang terang saja terkadang tidak selalu berjalan seperti yang kita inginkan, terkadang terjadi salah pemahaman antara komunikator dan komunikan, sehingga terjadi noise atau gangguan ketika berkomunikasi. Gangguan komunikasi adalah segala sesuatu yang menghambat atau mengurangi kemampuan kita untuk mengirim dan menerima pesan12. Begitu juga yang terjadi dalam suatu komunitas, organisasi atau kelompok hingga antara komunitas, organisasi, kelompok dan budaya dengan komunitas, kelompok lainnya. Itulah yang terjadi antara suku anak dalam atau orang rimba denga orang terang yang sangat berbeda dari banyak aspek.

\section{LANDASAN TEORI}


Komunikasi dapat terjadi dalam beberapa bentuk diantaranya dalam bentuk komunikasi personal dan kelompok. Selain itu komunikasi juga dapat bersifat tatap muka dan melalui perantara media. Dalam prosesnya komunikasi terbagi dalam dua macam komunikasi yaitu komunkasi aktif dan komunkasi pasif. Komunikasi aktif merupakan suatu proses komunikasi yang berlangsung dengan aktif antara komunikator dengan komunikan. Komunikasi dapat dibagi menjadi beberapa bentuk yaitu:

1. Komunikasi Intrapersonal

Komunikasi intrapersonal adalah komunikasi dengan diri sendiri. Hal ini menyangkut proses disaat diri menerima stimulus dari lingkungan untuk kemudian melakukan proses internalisasi. Adapun fungsi dari komunikasi intrapersonal adalah:

a. Untuk mengembangkan kreatifitas imajinasi, memahami, dan mengendalikan diri, serta meningkatkan kematangan berpikir sebelum mengambil keputusan.

b. Komunikasi ini akan membantu seseorang atau individu agar tetap sadar akan kejadian sekitarnya.

2. Komunikasi Interpersonal

Secara umum komunikasi interpersonal (komunikasi antar pribadi) dapat diartikan sebagai proses pertukaran makna orang- orang yang saling berkomunikasi. Komunikasi ini dilakukan oleh dua orang atau lebih dan terjadi kontak langsung dalam bentuk percakapan. Dapat berlangsung dengan berhadapan muka atau melalui media komunikasi, antara lain pesawat telpon, atau radio kounikasi. Komunikasinya bersifat dua arah, yaitu komunikator dan komunikan yang saling bertukar fungsi.

3. Komunikasi Kelompok

Adalah interaksi tatap muka antara tiga orang atau lebih dengan tujuan yang telah diketahui, seperti berbagi informasi, pemecahan masalah yang mana anggotaanggotanya dapat mengingat karakteristik pribadi anggota yang lain secara tepat.

4. Komunikasi Organisasi

Komunikasi organisasi secara sederhana dapat didefinisikan sebagai komunikasi antar manusia yang terjadi dalam konteks organisasi. Dari pengertian tersebut maka kita dapat memahami bahwasannya komunikasi organisasi adalah proses komunikasi yang berlangsung secara formal maupun non formal dalam sebuah system yang disebut organisasi.

5. Komunikasi Massa

Suatu proses dimana organisasi media memproduksi dan meyebarkan pesan kepada public secara luas. Disisi lain komunikasi massa juga diartikan sebagai proses komunikasi dimana pesan dari media dicari, digunakan dan dikonsumsi oleh audiens. Dari batasan singkat tersebut, kita dapat melihat bahwasannya karakteristik utama komunikasi massa adalah adanya media massa sebagai alat dalam penyebaran pesannya.

\section{METODE PENELITIAN}

Penelitian ini merupakan jenis penelitian lapangan Field Research yang bersifat kualitatif. Penelitian kualitatif yaitu penelitian yang memaparkan dan menggambarkan hasil penelitian secara objektif terhadap keadaaan dan karakteristik pelaku yang ditemui dilapangan untuk mendeskripsikan dan menganalisa fenomena, peristiwa, aktifitas sosial, sikap, kepercayaan, persepsi, pemikiran orang secara individual atau kelompok. Kemudian penulis menggunakan model penelitian Kualitatif yaitu diuraikan kata-kata menurut pendapat informan sesuai dengan pertanyaan penelitian. Penelitian ini dilakukan pada Suku Anak Dalam berlokasi Desa Sekamis Kecamatan Batang Asai 
Kabupaten Sarolangun Provinsi Jambi. Penelitian ini dilakukan selama 3 bulan, dari bulan Januari sampai bulan Maret 2019.

\section{HASIL DAN PEMBAHASAN}

Analisa penulis berdasarkan temuan data dilapangan, setidaknya ada tiga konteks beserta konten komunikasi Suku Anak Dalam dari beberapa bentuk komunikasi yang dilakukan oleh Suku Anak Dalam pada interaksi sosialnya dalam kehidupan sehari-hari, 


\section{a. Komunikasi Interpersonal}

Secara struktural telah dikethui bahwa kepela suku menjadi pemimpin tertingi dalam satu rombong Suku Anak Dalam, namun karena keagaliteran yang mereka miliki membuat kepala suku bukanlah orang yang menjadi populer dalam pilihan-pilihan yang Suku Anak Dalam sukai untuk berkomunikasi. Penulis menanyakan kepada beberapa Suku Anak Dalam. Siapa yang paling disukai untuk meminta nasehat ketika ada permasalahan internal meraka? Sangat bermacam-macam jawaban penulis terima.

Seperti jawaban dari Fendi dari masyarakat Suku Anak Dalam mengatakan: "Tidak jugo, masih ado yang lain tempat meminta nasehat selain dari kepalo suku, tergantung masalahnyo apo. Ado Dukun, Tengganai, Debalang Batin, dan Menti. Tugas dari kepalo suku itu biso mengurus masyarakat dengan orang terang atau kelompok yang lain".

Pandangan tersebut juga dikemukakan oleh Asmadi yang mengatakan bahwa: "Yo, Kepalo Suku itu biso jugo mengawasi kelompoknyo tidak mesti hal-hal kecil ditanyokan kepadonyo, masih banyak dibawah kepalo suku tempat kito batanyo". (Wawancara, 19 Februari 2019)

Hal itu setidaknya telah mencerminkan bahwa kepala suku bukan orang yang selalu disukai oleh beberapa anggota rombong Suku Anak Dalam. Walaupun pada akhirnya permasalahan yang tidak terselesaikan menjadi pemikiran kepala suku.

Struktur kemasyarakatan yang ada didalam masyarakat Suku Anak Dalam sama hal nya dengan sistem orang terang, artinya semua itu hanya berlaku jika ada hal-hal prosedural. Namun dalam berkomunikasi sehari-hari mereaka sangat egaliter tanpa melihat dan mengikuti alur birokrasi yang mereka miliki.

Komunikasi interpersonal Suku Anak Dalam berbentuk saluran total yaitu setiap anggota kelompok dijamin dapat berkomunikasi secra langsung kepada siapapun tanpa melalui perantara. Dalam gambar memang penulis hanya mengambil contoh pada jajaran penghulu. Karena menurut penulis hal ini telah mewakili seluruh Suku Anak Dalam.

\section{b. Komunikasi Kelompok}

Komunikasi kelompok atau komunikasi antar rombong Suku Anak Dalam memakai perantara yaitu kepala suku. Contohnya dalam internal satu rombong suku anak dalam sebut saja rombong suku anak dalm 1, ada suatu hal penting yang harus dikomunikasikan kepada rombong lain atau rombong suku anak dalam 2, misalnya ada yang meninggal salah satu anggota rombong orang rimba 1 dan harus segera diinformasikan ke rombong suku anak dalam 2, dikarenakan jarak antara kedua rombong tersebut sangat berjauhan, sangat tidak dimungkinkan untuk semua suku anak dalam pada rombong 1pergi menyampaikannya, secara struktural adalah 
manti yang pergi menyampaikannya dan itu sudah ditentukan dan sangat kecil kemungkinan Suku Anak Dalam untuk tidak melakukannya. Jika kita gambarkan seperti yang terlihat dibawah ini.

Pernyataan diatas seperti disampaikan oleh Nipan sebagai Wakil Kepala Suku yang mengatakn bahwa:

"Kito ini kan tidak tinggal satu tempat, ado sanak kito ditempat lain dan itu adalah tugas seorang Manti untuk menginformasikan ke kelompok lain jiko ado hal penting yang harus disamapaikan. Seperti jiko ado yang meninggal misalnyo dan termasuklah berunding-berunding yang lain". (Wawancara, 15 Februari 2019)

Pernyataan diatas penulis perjelas dengan gambar Komunikasi Suku Anak Dalam antar kelompok.

Gambar 1.5 Komunikasi Suku Anak Dalam Antar Kelompok Atau Rombong.

$\begin{array}{llll}\text { R SAD } 1 & \text { S SAD } 1 & \text { S SAD } 2 & \text { R SAD } 2\end{array}$

Ket $\quad$ : R SAD $1 \quad: \quad$ Rombong suku anak dalam 1

R SAD 2 : $\quad$ Rombong suku anak dalam 2

KS SAD 1 : Kepala Suku suku anak dalam 1

KS SAD 2 : Kepala Suku suku anak dalam 2

Komunikasi berlansung melalui saluran yang sudah ditentukan oleh struktural Suku Anak Dalam mengikuti sistem hirarki organisasi. Disini kita lihat bahwa Kepala Suku tiap rombong menjadi perantara dalam komunikasi antar rombong Suku Anak Dalam.

c. Komunikasi Organisasi

Suku Anak Dalam sudah terpola hidup secara berkelompok dengan melakukan pengaturan tersendiri terhadap kelompok. Masing-masing memiliki organisasi di dalam organisasi inilah Suku Anak Dalam menjalin komunikasi yang intensif untuk kelangsungan hidupnya, sama-sama memikirkan agar kelompok/organisasi mereka tetap bertahan dan setiap kelompok ini dipimpim oleh Kepala Suku yang merupakan hasil kompetisi yang ketat dikalangan laki-laki. 
Seperti hasil wawancara dengan Nipan sebagai wakil Kepala Suku mengataka:

"Untuk menjadi Kepalo Suku itu harus mendapat persetujuan/anggota kelompok. Pemimpin harus menguasai hukum adat,peka dan pandai menyelesaiakn setiap masalah, pandai berburu, mempunyai kepampuan sebagai dukun. Kedudukan Kepalo Suku diwariskan pado anak lanang atau menantu lanang. Jiko Kepalo Suku berhenti atau meninggal dunia mako dari beberapo anak kandung lanang atau menantu akan dipilih salah satunyo sebagai penggantinyo dan setiap anggota kelompok memiliki hak untuk memilih". (Wawancara, 19 Februarai 2019)

Sistem sosial dan budaya mereka lebih kompleks dan terpadu dengan sistem hierarki kepemimpinan politik dengan banyak tingkat dan gelar. Hirarki bukan semata-mata menyangkut hak komando yang jelas dan diduduki berdasarkan kemampuan masingmasing orang. Mereka harus mendapatkan dukungan dan persetujuan dari masyarakatnya lewat berbagai cara. Dari beberapa syarat diatas, faktor yang paling menentukan adalah pengakuan dan dukungan dari kekuatan politik di luar Suku Anak Dalam, yaitu masyarakat desa atau orang terang.

Contoh lain seperti interaksi Suku Anak Dalam dengan perusahaan luar telah memberikan pengaruh besar terhadap perubahan cara komunikasi mereka, keberadaan waris dan jenang menjadi ujung tombak penangganan masalah yang dihadapi Suku Anak Dalam ketika secara internal tidak dapat menyelesaiakan menjadi penting keberadaannya karena dikalangan Suku Anak Dalam sendiri tidak ada pemimpin tertinggi yang menjadi panutan bagi semua organisasi yang ada.

Berdasarkan hasil survey Suku Anak Dalam di Desa Sekamis belum secara maksimal memanfaatkan alat komunikasinya sebagai media informasi mereka meskipun rata-rata mereka telah memiliki hanphone, namun hanphone yang mereka miliki terlebih digunakan sebagai hiburan, seperti pemutaran musik dan hanya sebagian kecil hanphone digunakan alat komunikasi.

Tetapi hasil wawancara dengan Milang sebagai Kepala Suku mengatakan bahwa:

"Belum maksiamal memanfaatkan alat komunikasi meskipun sudah banyak yang memilikinyo, kami masih mengunakan Jenang untuk mengiformasikan kepada masyarakat jiko ado perundingan/musyawarah, baik masalah dalam kelompok ataupun dengan orang terang". (Wawancara, 19 Februarai 2019)

\section{KESIMPULAN DAN SARAN}


Berdasarkan hasil penelitian maka penulis memberikan kesimpulan bahwa ada beberapa konteks Komunikasi Suku Anak Dalam, yaitu: Komunikasi Interpersonal, Komunikasi Kelompok, dan Komunikasi Organisasi. Tetapi musyawarah/berunding masih mereka pakai setiap menyelesaikan masalah.

Pandangan hidup Suku Anak Dalam yang sangat berpegang teguh dengan aturan hukum dan adat istiadat perlu ditingkatkan, kebiasaan menjual lahan kepada masyarakat luar untuk alasan memenuhi kebutuhan hidup adalah persoalan yang perlu diberikan pemahahaman kepada Suku Anak Dalam, hal ini juga menjadi topik yang menarik untuk diteliti lebih lanjut tentang dampak negatif dari proses pembaharuan. Mereka menjadi konsumtif, mudah terpengaruh dan gampang ditipu.

\section{DAFTAR PUSTAKA}

Aswad Ishak dan Faiz Ayatullah, 2003,“Komunikasi \& Organisasi”, Yogyakarta; UPFE UMY

A.W Wijdaya, 1993, "Komunikasi dan Hubungan Masyarakat", Jakarta, Bumi Aksara.

Andrik Purwasito, 2002, "Komunikasi Multikultural", Surakarta, Muhammadiyah Universitas Press.

Andrik Purwasito, 2003, “Message Studies: Pesan Penggerak kebudayaan”,Surakarta, Ndalem Poerwahadiningrat Press.

Arni Muhammad, 2009, Komunikasi Organisasi, Jakarta: Bumi Aksara

B. Aubrey Fisher, 1978, Teori-teori Komunikasi, Bandung, Remaja Roesda Karya.

Bagong Suyanto \& Sutinah (ED.), 2005, "Metode Penelitian Sosial; Berbagai Alternatif Pendekatan", Jakarta: Kencana

Dedy Mulyana, 2001, "Ilmu Komunikasi Suatu Pengantar", Bandung: Remaja Rosdakarya.

Dedy Mulyana dan Jalaluddin Rakhmat, 2006, "Komunikasi Antar Budaya”, Panduan Komunikasi dengan Orang-orang berbeda Budaya, Bandung: Remaja Rosdakarya.

Departemen Pendidikan dan Kebudayaan, 1989, “Kamus Besar Bahasa Indonesia”, Jakarta: Balai Pustaka

P. joyo Subarjo, 1996, "Metode dalam Teori dan Praktek", Jakarta: Arcan , 1996.

Pawito, 2007, "Penelitian Komunikasi Kualitatif", Yogyakarta: IKiS Pelangi Aksara.

Rinto Adi, Heru Prasedja, 1991, "Langkah-langkah Penelitian Sosial", Jakarta: Arcan.

Reed Blake dan Edwin O Haroldsen. 2003, "Taksonomi Konsep komunikasi”, Surabaya: Papyrus.

Setiawan Jauhari, 2001, "Pedoman Penulisan Skripsi, Tesis, Desertasi”, Bandung: Rama Widya.

Sukardi, 2004, Metodologi Penelitian Pendidikan kompetensi dan praktiknya, Jakarta: Bumi Aksara

San Abede Pareno, 2002, "Kuliah Komunikasi”, Surabaya: Papyrus. Thomas Hill Long, 1979, Collins English Dictionary, London

W.J.S. Porwadarmita, 1976, "Kamus Umum Bahasa Indonesia”, Jakarta: PN Balai Pustaka

Winarno Surakhmad, 1998, "Pengantar Penelitian IImiah; Dasar, Metode dan Tekhnik", Bandung: Tarsito 
46 | Ardiyansyah; Tinjauan Konteks Dan Konten Komunikasi Pada Komunitas... 